Article

\title{
Minority Embeddedness and Economic Integration: Is Diversity or Homogeneity Associated with Better Employment Outcomes?
}

\author{
Neli Demireva ${ }^{1, *}$ and Anthony Heath ${ }^{2}$ \\ ${ }^{1}$ Department of Sociology, University of Essex, Colchester, CO4 3SQ, UK; E-Mail: nvdem@essex.ac.uk \\ ${ }^{2}$ Nuffield College, University of Oxford, Oxford, OX1 3UQ, UK; E-Mail: anthony.heath@nuffield.ox.ac.uk \\ * Corresponding author
}

Submitted: 21 September 2016 | Accepted: 27 February 2017 | Published: 28 March 2017

\begin{abstract}
Using data from the Managing Cultural Diversity Survey 2010 and the Ethnic Minority British Election Study 2010, we explore the activity and employment outcomes of majority and minority individuals in the UK, and examine their association with a variety of ethnic embeddedness measures. We do not find that white British respondents living in areas of high deprivation and diversity experience lower levels of economic activity or bad jobs. Deprivation rather than minority embeddedness stands out as the factor that serves to compound both majority and minority disadvantage. In the case of minorities, embeddedness does have some negative effects, although these are greatly attenuated once one takes into account the level of area deprivation.
\end{abstract}

\section{Keywords}

activity; employment; occupational attainment; migrants; minorities

\section{Issue}

This article is part of the issue "International Migration and Ethnic Integration", edited by Yaojun Li (University of Manchester, UK) and Anthony Heath (University of Oxford, UK).

(C) 2017 by the authors; licensee Cogitatio (Lisbon, Portugal). This article is licensed under a Creative Commons Attribution 4.0 International License (CC BY).

\section{Introduction}

Recent attempts to quantify social inclusion in Europe have been focusing almost exclusively on the rates of activity and employment among migrants and their offspring (Kahanec, 2013). Policy makers have been widely supportive of this pragmatic approach. In a world facing a number of shortages, be it jobs or housing, continuing migrant dependency on the state rather than contribution has the potential to upset the social status quo, to unnerve a majority population concerned with falling standards of living and to undermine the social pact that provides support for welfare regimes in particular, and democracies in general. Furthermore, many politicians remain sceptical of selective acculturation, multiculturalism and a strong reliance upon the co-ethnic community (Cameron, 2013), and often question whether migrants and minorities can prosper under scenarios where minorities remain apart from the mainstream and live 'parallel lives'. In the context of the UK, the impact of mi- grants on employment prospects featured significantly in the debates surrounding Brexit and are an indispensable part of any immigration speech (Cameron, 2011; May, 2012). In contrast to this popular sentiment of escalating fears, the academic stance has been that migrants contribute to the system rather than undermine it - they usually have better health outcomes than the average Briton, pay more in taxes and do not really compete for jobs with the majority (Dustmann \& Frattini, 2014).

Whereas this optimistic picture of migration can very well hold for the aggregate, different commentators have argued that it obscures the dire state of traditional working class white communities exposed to 'unbridled' diversity and the acute competition for resources in places which 'have been left behind'; that is to say, the ones that lack the structural means to weather profound changes (Casey, 2016; Goodhart, 2013).

Using data from the Managing Cultural Diversity Survey 2010 and the Ethnic Minority British Election Study 2010, we explore the activity and employment outcomes 
of majority and minority individuals in the UK, and examine their association with a variety of measures of community embeddedness. We do not find that white British respondents living in areas of high diversity experience lower levels of economic activity or bad jobs. Quite the contrary, they appear to benefit in such scenarios. Deprivation rather than percent migrant and minority in the local area stands out as the factor that serves to compound both majority and minority disadvantage.

\section{The Impact of Minority Embeddedness and Deprivation}

This paper focuses on the economic prospects of the white British, and migrants and minorities, accounting for their embeddedness in local communities. In order to do so, we take into consideration not only individual characteristics but characteristics of the local areas as well such as deprivation, degree of urbanization and level of minority embeddedness. We interpret minority embeddedness as the share of migrants and minorities present in the local area. The greater the share, the greater the minority embeddedness. Effectively, we consider the distinction between the white British on the one hand and on the other hand individuals who are 'outgroupers'; that is to say, the latter belong to an ethnic group other than white British. In this way, we argue that the paper is able to capture a fundamental distinction at the community level between the white British majority and a range of minority groups (comprising of migrants and the second generation); we can consequently comment on the overall implications of ethnic concentration and diversity both on minorities themselves and on their white British neighbours. However, we acknowledge that our sample sizes are not sufficiently large to permit a fine-grained analysis of specific local conflicts between particular ethnic groups and the white majority.

\subsection{White British}

Minority embeddedness for the majority group essentially entails more diversity (Abascal \& Baldassarri, 2015). The literature on this association has focused on social trust rather than economic outcomes, but for a few exceptions. Dustmann, Frattini and Preston (2013), Dustmann, Frattini and Halls (2010) and Manacorda, Manning and Wadsworth (2012) show that regional migration flows hardly affect the mean wage; however, there are indications that majority members positioned at the lower end of the majority wage distribution are adversely impacted by incoming migrants who create a surplus in the economy by virtue of having greater human capital than the majority population while being ready to settle for unskilled jobs. In other words, low-skilled majority members are possibly worse off due to migration.

One thing to point out is that, unlike the research on social trust, these studies focus on the consequences of migration rather than on the consequences of diver- sity, and explore regional differences rather than local area variation. In this paper, we have chosen to align ourselves more closely with the postulates of conflict theory, which suggest that as societies diversify, there is growing competition for resources which brings about tensions between the majority groups, migrants and their descendants (Putnam, 2007). Our focus is on local communities. Conflict can be expected to be greater in deprived areas - the fewer the resources to be redistributed, the greater the competition. The literature from the US finds some support for these ideas (Alesina \& La Ferrara, 2002; Putnam, 2007); however, the data from the UK suggests a much more moderate effect of diversity which usually disappears once controls for deprivation and economic competition are introduced at the community level (Demireva \& Heath, 2014; Laurence, 2011; Laurence \& Heath, 2008; Letki, 2008; Sturgis, Brunton-Smith, Read, \& Allum, 2011). It appears that, at least in Britain, it is deprivation that undermines the social glue rather than diversity.

In this paper, we argue that similarly to social trust, the economic prospects of individuals merit greater attention. Some authors speculate that with growing diversity there might be greater competition for jobs (Reyneri \& Fullin, 2011). Under such conditions, it is not only the wages of majority members that can be undercut. It is possible that their labour market activity as well as the opportunity to achieve a higher status job is threatened. Other scholars insist that migrants and the majority occupy different economic niches and that this occupational segregation can extend to the second generation as well (Dustmann \& Frattini, 2014). If the latter is true the activity and employment status of the white British should be unaffected by diversity. This association can be of particular interest to policy makers who are concerned with the levels of unemployment both among majority and minority members, and the possible burden on the welfare system (Cameron, 2011).

If minority embeddedness induces greater competition for jobs, we would expect that:

Hypothesis 1: As diversity increases, the employment probability of white British respondents will decrease. If migrants and minorities are rewarded proportionately to their human capital, there will be greater competition for high status jobs since migrants in general have higher levels of human capital than white British individuals (Dustmann et al., 2013); and the second generation has surpassed the majority in terms of educational attainment (Heath \& Brinbaum, 2007).

Yet, it is possible that diversity just captures the selective sorting of individuals-white British individuals with poorer economic prospects concentrate into more deprived areas that happen to be also more diverse. Thus:

Hypothesis 2: Deprivation rather than levels of diversity will account for the deterioration in the economic 
prospects of the white British. It is also likely that diversity does not increase competition in all areas but only in the poorly resourced ones. That is to say, in areas experiencing economic strain, diversity will be associated with the exacerbation of conflict. In this case, we will observe a significant interaction effect between deprivation and diversity.

\subsection{Migrants and Minorities}

The question of whether it is possible for migrants and minorities to achieve upward social mobility while being embedded in communities of co-ethnics and pan-ethnics has been a long standing concern for migration scholars and policy makers. Notably, segmented assimilation theory postulates that some immigrants (Portes \& Rumbaut, 2001; Portes \& Zhou, 1993) may never catch up in terms of earnings with the white middle class, acculturating into the poor, underdeveloped segment of the receiving society (Zhou, 1994); while for others strong ethnic community may nevertheless lead to economic advancement.

Providing a consistent empirical test for segmented assimilation has proved difficult. Segmented assimilation places a focus on the second generation and their chances of occupational mobility (Zhou, 1994). Yet, it is in the first generation that the impact of ethnic embeddedness can be particularly strong: migrants who have little knowledge about institutions in the receiving society can be greatly helped by the existence of co-ethnic organizations that facilitate the first contact with majority employers (Waters, 1999). Important jobs can exist in ethnic economies that minimize unemployment spells (Alba \& Nee, 1997). In contrast, other scholars argue that over time, for women, and in the second generation, this positive impact can attenuate and even disappear (Koopmans, 2015). Women with little access to the mainstream society can be encouraged to observe strict social norms and withdraw from the labour market; reservation wages for the second generation individuals with strong co-ethnic ties can be high, leading to higher levels of unemployment. Ultimately, the quality of jobs in the ethnic economy (similarly if these have been obtained through ethnic networks) can be poor; thus, creating the opportunity for stickiness of low status outcomes across generations. Policy makers are particularly suspicious of growing minority embeddedness, usually interpreting it as refusal to embrace integration (Cameron, 2011). Such segregation from the mainstream society is often brought up as a possible explanation for the poor employment prospects of South Asian Muslim communities in Britain (Phillips, 2005).

If these pessimistic predictions hold:

Hypothesis 3: We will observe a negative association between levels of minority embeddedness and the employment prospects of migrant and minority members.
Hypothesis 4: If however, occupying migrant/minority niches reflects on a number of selective processes and constraints (apart from preferred proximity to family and co-ethnic support networks) such as the availability of cheap housing at the point of migration, when we control for deprivation, this association will disappear.

Thus, we will argue that if migrant and minority individuals (Fryer, Pager, \& Spenkuch, 2011) are concentrated in disadvantaged neighbourhoods and regions - the ones with greater economic volatility, unemployment, and bad jobs-leaving behind poor employment prospects can prove near impossible. Local area deprivation can impact both the pool of available jobs as well as the information transmitted about openings (Cutler, Glaeser, \& Vigdor, 1997).

Several studies provide an examination of segmented economic assimilation with UK data. Using UKLFS 1992-2009, Patacchini and Zenou (2012) find some support for a positive association of local social interaction between people of the same ethnicity which is significant for Bangladeshi and Chinese workers, but not for Pakistanis or Indians. These associations are strongest for the most recent arrivals. Feng, Flowerdew and Feng (2015) establish that the ethnic penalty associated with the risk of becoming unemployed and the probability of finding employment is partly explained by geographical deprivation. Ethnic diversity helped women to retain employment but did not affect men. Deprivation partially explained the ethnic minority disadvantage in the English labour market. This research was based on the ONS Longitudinal Study (1991-2001). These studies demonstrate the need for a more comprehensive investigation of local area embeddedness and for a distinction between majority and minority populations; and the present paper aims to fill this important gap.

\subsection{Data and Methods}

In order to test our hypothesis, we need data for both majority and migrant and minority members. This study makes use of two major datasets with comparable questionnaire structures designed to measure a range of economic, social and political outcomes. Both were administered in 2010. The first is the Managing Cultural Diversity Survey (MCDS). This survey was a random location quota sample of 1650 individuals: 864 white British respondents; and through an ethnic minority booster sample, 786 minority individuals. ${ }^{1}$ The second dataset is the 2010 Ethnic Minority British Election Study (EMBES) which focuses only on minority respondents. We would have liked to be able to use the British Election Study 2010 for our majority sample; however, this survey does not ask about the activity and occupational status of respondents. The EMBES was a random probability sample that covers the major ethnic minority groups in the UK with

\footnotetext{
${ }^{1}$ Of the 1666 respondents, there were 5 missing values for the variable age. All retired respondents and students have been excluded.
} 
a sample of 2782 minority individuals. Thus, while the first dataset allows us to compare white British individuals with migrant and minority ones, the second brings us closer to understanding the differences between minority groups. The minority sample in MCDS is small and does not allow for a fine distinction between migrant and minority groups; yet, we achieve this with EMBES.

\subsection{Geographical Units}

A frequent criticism of diversity studies, such as that of Putnam (2007), is that they employ area units of analysis that vary greatly in size and, therefore, in their potential diversity mix, and are thus incomparable (Dawkins, 2008). The MCDS uses Middle Super Output Areas (MSOAs: minimum number of households 2000, maximum 6000) as the primary sampling unit while the EMBES sample uses Lower Super Output Areas (LSOAs: minimum number of households 400, maximum 1200). Compared to wards, MSOAs and LSOAs are felt to be more appropriate for this analysis due to the fact that wards differ greatly in size. We are also better placed to capture economic local area effects along the lines of ethnic niches through MSOAs and LSOAs rather than regions. We acknowledge however the difference in size between the two geographical units and the difficulties this may present for the analysis. However, the use of two datasets, bearing in mind their constraints, allows us to cross-check our results; and in this way yields the analysis to spatial sensitivity. The MCDS sampled 200 areas with the average of 7.95 respondents per unit. The EMBES sample consists of data points spread across 582 LSOAs with the average size of the cluster being 5.5 individuals.

\subsection{Dependent Variables}

We distinguish between several outcomes which reflect the economic prospects of individuals: the probability of being active (excluding retired respondents and students) and the probability of being employed, which are standard measures of labour market engagement (Van Tubergen, Maas, \& Flap, 2004). To this, we add a measure of occupational status which reflects on the mobility prospects of individuals (Heath \& Yu, 2005). Unfortunately, the measure of wage remuneration is imprecise, with lots of non-response, in both datasets. In addition, in MCDS, the occupational status variables captures occupational status of current or any job that the respondent has held, with those that have never held a job excluded; while in EMBES, the measure refers to the status of the current position of the respondent.

\subsection{Independent Variables}

\subsubsection{Demographics}

\subsubsection{Ethnic Group}

The UK studies on minority embeddedness highlight the necessity of distinguishing between the outcomes of different ethnic groups (Patacchini \& Zenou, 2012). We distinguish between the outcomes of the majority and four minority groupings with MCDS data: Black Caribbeans and Black Africans, Indians, Pakistani and Bangladeshis and other respondents. With EMBES data, we can draw a more detailed distinction between minority groups. Unfortunately, however, EMBES has poor coverage of other white respondents, which we acknowledge as a limitation of the data.

We know from previous research that age, gender and generational status (Lessard-Phillips, 2015; Luthra, Platt, \& Salamońska, 2014) have profound effects upon the opportunities and constraints faced by migrant and minority groups, with South Asian minority women experiencing lower levels of activity and second generation members usually hypothesized to have similar outcomes to the majority. Our EMBES data would allow us to closely examine generational patterns.

At the individual level we distinguish between coethnic organizations and co-ethnic friends which have been shown to be very important as they reflect on the bridging and bonding opportunities of individuals (Demireva \& Heath, 2014; Heath \& Demireva, 2014; Lancee, 2012).

\subsubsection{Minority Embeddedness}

We operationalize minority embeddedness at the local area level as the percentage of non-white British, thus drawing distinction to the exposure of minorities to the majority population and vice versa. ${ }^{2}$

\subsubsection{Deprivation}

The possible negative effect of socio-economic disadvantage will also be examined through looking at the Index of Multiple Deprivation (IMD)-economic cleavages are strong predictors of societal disintegration and may signal higher rates of competition (Laurence, 2011; Sturgis et al., 2011). We use IMD 2010 which is an official measure of small areas. It is based on seven domains: income, employment, education, skills and training, health, crime, barriers to housing and services, and living environment deprivation (for information on its range, see the Appendix).

\footnotetext{
${ }^{2}$ We have replicated the results with percentage of co-ethnics as well. Full tables are available upon request.
} 


\subsubsection{Other Individual Level Factors}

Qualifications are at the heart of the human capital framework (Heath \& Yu, 2005). We introduce them in our last model because we want to compare their explanatory power with that of community level predictors. Thus, community level measures can hold an important place in the aggregate but individual selection along the propositions of the human capital framework can be a much more powerful predictor of disadvantage. Social housing has been shown to significantly lower the odds of different ethnic groups in terms of trust and engagement (Demireva \& Heath, 2014); and religiosity can potentially tap important cultural differences (Koopmans, 2015). With the MCDS data we can also control for factors such as residential stability and degree of urbanization.

\subsubsection{Models}

Our response variables are dichotomous; therefore we use the logit link:

$\operatorname{Pr}($ economic integration outcome $=1)=\beta_{0}+$ Bage + $\beta$ gender $+\beta$ marital status $+\beta$ ethnic group (in minority models) + $\beta$ generation (in minority models) [Model 0] $+\beta$ percent non-white British [Model 1] + Bco-ethnic bonding [Model 2] + BInIMD [Model 3] + Breligiosity + Beducation + degree of residential stability [Model 4]

We also have models with degree of urbanization and tenure and those are available upon request.

\subsubsection{Interpretation of Effects}

We use average marginal effects, computed at different values of the $X$ variables. This allows us to interpret the results intuitively as percentage point differences and provides a basis for comparison between different coefficients.

\section{Descriptive Statistics}

Several clear patterns emerge from the descriptive Tables 1 and 2. As is well-known, minorities are much more likely than the white British to live in diverse areas. Thus on average white British respondents in MCDS live in relatively homogeneous areas (containing on average 22 percent minorities) whereas minority respondents are much more likely to live in diverse areas: Pakistanis and Bangladeshis for example live in areas where roughly 50 percent of residents belong to a minority group. Pakistanis and Bangladeshis also live in areas with the highest scores on the index of multiple deprivation. However it is important to note that not all spatially concentrated minority groups reside in very deprived areas. Indians, who live in areas with a relatively high presence of minorities, nevertheless experience less local area deprivation than the black or other South Asian groups. However, if we zoom in on the most deprived areas (those above the $75^{\text {th }}$ percentile of deprivation), we see that the levels of minority presence jump for all groups-for example, white British respondents who live in these most deprived areas are much more likely to have minority neighbours (the percentage of minorities in their area rising from 22 to 36 percent). These patterns highlight the importance of conditioning on deprivation when analysing the effect of minority embeddedness.

The ethnic groups differ not only in regards to the areas in which they live but also in terms of their individual characteristics as well. In general, minority respondents in our data are younger than their white British counterparts, especially the combined Pakistani/Bangladeshi group. Minorities on average appear better educated (higher percentages with degrees) than the white British. $^{3}$ In the EMBES data, Black Africans and Indians are among the most educated respondents; almost half of the respondents in these two groups have a de-

Table 1. Demographic, socio-economic, and community characteristics by ethnic group. Source: MCDS (2010); 298 retired and 113 in full time education respondents excluded from working age sample of 1666.

\begin{tabular}{|c|c|c|c|c|c|c|c|c|c|}
\hline Ethnicity & $\begin{array}{l}\text { Mean } \\
\text { Prop } \\
\text { Non-white } \\
\text { Brit }\end{array}$ & $\begin{array}{l}\text { Mean Prop } \\
\text { non-white } \\
\text { Brit at high } \\
\text { deprivation }\end{array}$ & $\begin{array}{l}\text { Mean } \\
\text { IMD }\end{array}$ & $\begin{array}{l}\text { Education } \\
\text { Degree }\end{array}$ & $\begin{array}{l}\text { Co-ethnic } \\
\text { Organization }\end{array}$ & $\begin{array}{l}\text { Co- } \\
\text { ethnic } \\
\text { Friends }\end{array}$ & Married & $\begin{array}{l}\text { Mean } \\
\text { Prop } \\
\text { Co- } \\
\text { ethnic }\end{array}$ & $\mathrm{N}$ \\
\hline White British & 0.22 & 0.36 & 2.85 & 35.65 & 42.71 & 5.32 & 57.41 & 0.78 & 625 \\
\hline $\begin{array}{l}\text { Black Caribbean } \\
\text { and African }\end{array}$ & 0.47 & 0.49 & 3.29 & 42.66 & 10.49 & 24.48 & 37.06 & 0.07 & 127 \\
\hline Indian & 0.54 & 0.49 & 2.99 & 60.12 & 12.27 & 20.25 & 63.8 & 0.18 & 155 \\
\hline $\begin{array}{l}\text { Pakistani and } \\
\text { Bangladeshi }\end{array}$ & 0.54 & 0.61 & 3.43 & 44.06 & 10.49 & 16.08 & 66.43 & 0.17 & 139 \\
\hline Other & 0.43 & 0.55 & 2.96 & 50.45 & 13.06 & 35.61 & 56.68 & 0.05 & 306 \\
\hline Total & & & & & & & & & 1,255 \\
\hline
\end{tabular}

${ }^{3}$ It is possible that having Pakistanis and Bangladeshis in a joint group in the MCDS masks the disadvantaged position of Bangladeshis in this respect. In comparison, the proportion of Bangladeshi with a degree in the EMBES sample is 0.22 well below the 0.29 for white British. 
Table 2. Demographic, socio-economic, and community characteristics by ethnic group. Source: EMBES (2010); 238 retired and 277 in full time respondents were excluded from sample of working age population of 2753.

\begin{tabular}{|c|c|c|c|c|c|c|c|c|c|c|c|}
\hline Ethnicity & $\begin{array}{l}\text { Mean } \\
\text { Prop } \\
\text { Non- } \\
\text { white } \\
\text { Brit }\end{array}$ & $\begin{array}{l}\text { Mean } \\
\text { Prop non- } \\
\text { white Brit } \\
\text { at high } \\
\text { depriva- } \\
\text { tion }\end{array}$ & $\begin{array}{l}\text { Mean } \\
\text { IMD }\end{array}$ & $\begin{array}{l}\text { Educa- } \\
\text { tion } \\
\text { Degree }\end{array}$ & $\begin{array}{l}\text { Co- } \\
\text { ethnic } \\
\text { Organ- } \\
\text { ization }\end{array}$ & $\begin{array}{l}\text { Co- } \\
\text { ethnic } \\
\text { Friends }\end{array}$ & Married & $\begin{array}{l}\text { Social } \\
\text { Hous- } \\
\text { ing }\end{array}$ & $\begin{array}{l}\text { 2nd } \\
\text { Gener- } \\
\text { ation }\end{array}$ & $\begin{array}{l}\text { Mean } \\
\text { Prop } \\
\text { co- } \\
\text { ethnic }\end{array}$ & $\mathrm{N}$ \\
\hline $\begin{array}{l}\text { Black } \\
\text { Caribbean }\end{array}$ & 0.34 & 0.42 & 4.22 & 28.81 & 29.90 & 42.04 & 33.33 & 37.52 & 56.28 & 0.08 & 500 \\
\hline $\begin{array}{l}\text { Black } \\
\text { African }\end{array}$ & 0.36 & 0.43 & 4.31 & 49.81 & 33.79 & 47.52 & 40.27 & 48.47 & 13.55 & 0.07 & 505 \\
\hline Indian & 0.39 & 0.55 & 3.97 & 49.15 & 41.70 & 46.76 & 65.70 & 8.19 & 32.08 & 0.16 & 513 \\
\hline Pakistani & 0.47 & 0.60 & 4.34 & 32.34 & 23.41 & 56.29 & 66.62 & 11.98 & 36.98 & 0.26 & 641 \\
\hline Bangladeshi & 0.50 & 0.59 & 4.39 & 22.59 & 26.32 & 62.59 & 67.04 & 43.70 & 25.93 & 0.18 & 257 \\
\hline $\begin{array}{l}\text { Other } \\
\text { ethnicity }\end{array}$ & 0.33 & 0.44 & 4.25 & 20.56 & 8.41 & 21.50 & 27.10 & 51.4 & 71.03 & 0.08 & 98 \\
\hline
\end{tabular}

gree. Social housing, which is closely related to deprivation is high among Black Africans and Bangladeshis whereas the proportion of social renters among Indians is rather small.

\section{Multivariate Analysis}

Tables 3, 4 and 5 present logistic regression results on the likelihood of achieving economic integration. In each table we show the results for three sets of model, one set looking at rates of economic activity, the second set looking at the probability of employment (among those who are economically active), and the third set looking at the probability of achieving a professional or managerial position. We first introduce the potentially 'confounding' variables of age, gender and marital status (and the ethnic minority groups and generation in the models confined to minorities in Tables 4 and 5). We then introduce a measure of minority embeddedness (the percentage in the area who are not white British) in order to provide a first test of Hypotheses 1 and 3. To this we add two further measures of embeddedness-membership of a co-ethnic organization and of co-ethnic friends-in order to provide a more nuanced test: arguably minority embeddedness at the local area level, as measured by the percentage non-white British, represents just an opportunity for contact rather than established networks. These measures of co-ethnic friends and organizations provide a more direct test of theories of embeddedness.

The next stage is to introduce our measure of area deprivation in order to test hypotheses 2 and 4 . Finally we include further predictors (educational level, and residential stability) which might be, to varying extents, en- dogenous to our key concepts of embeddedness and area deprivation. Thus growing up in a deprived area may limit one's educational opportunities. Tables 3 and 4 are based on the MCDS data, and enable us to compare patterns for ethnic minority and white British respondents. Table 5 is based on the EMBES data and is restricted to ethnic minority respondents only.

Table 3 uses the MCDS data to look at the patterns among white British respondents, thus enabling us to test Hypotheses 1 and 2.

Model 1 introduces the measure of the percentage non-white British in the area, which provides us with our first test of Hypothesis 1. This measure has no significant effect whatsoever on the economic activity or employment chances of the white British, and surprisingly has a significant positive effect on white British occupational chances. Furthermore, the more nuanced measures of co-ethnic organization and friends in model 2 also prove to be non-significant in the case of economic activity and employment chances, although they have contradictory effects (which will tend to cancel out) in the case of occupational attainment.

These results thus rather conclusively lead us to reject Hypothesis 1: the presence of minorities does not harm the employment patterns and prospects of the white British. If anything the reverse is the case especially in terms of occupational attainment with this positive association stronger controlling for deprivation. ${ }^{4}$

Moving on to our test of Hypothesis 2 with model 3, we find that area deprivation impacts negatively on the chances of the white British being economically active, gaining employment and securing higher-level jobs. Model 4 shows that educational level has the expected

\footnotetext{
${ }^{4}$ Full tables with interaction effects available upon request.
} 
strong and positive effects on all three outcomes, and that it also partially explains the effects of area deprivation. (This could be due either to negative selection of less educated individuals into deprived areas, or it might be that living in a deprived area lowers educational attainment. Both processes may well occur but we cannot disentangle their importance from cross-sectional data such as we are using here). Nevertheless, the effect of area deprivation remains significant and negative for all three outcomes among white British respondents. This thus provides strong support for Hypothesis 2, namely that it is deprivation rather than diversity which accounts for any white British disadvantage, at least with respect to economic activity and employment chances.

In Table 4 we then use the MCDS dataset to explore the effects of embeddedness and area deprivation on the economic outcomes of ethnic minorities. First we find some significant differences between minorities, with the Black and combined Pakistani/Bangladeshi groups having lower rates of economic activity, employment and occupational attainment than the Indian group. This is consistent with previous research using other sources. We also find that age, gender and marital status work in the same was as they did for the white British in Table 3, although among minorities the effect of gender on economic activity is much stronger, while the age effects are relatively small. This raises some interesting questions for future research about minority career progression.

Moving on to the test of Hypothesis 3, we find that, unlike the situation among the white British, minority embeddedness does indeed have significant negative effects on economic activity, supporting Hypothesis 3, although not on the other two outcomes. Moreover, the more nuanced measures of embeddedness (at the individual level) in model 3 do not in general have the anticipated mediating role, except in the case of occupational attainment. The sign of the association differs in MCDS and EMBES but we are inclined to go with the much larger and richer sample of EMBES. The positive association with friends in MCDS could be due to the fact that the measure of occupational attainment captures the status of any job of the respondent and coethnic friends are perhaps important for holding a good job over the life time of the individual. Area deprivation does have the expected negative effect on economic activity and employment chances, supporting Hypothesis 4. In model 4 this effect turns out to be largely mediated by level of education, which, as in the case of the white British, is one of the most powerful predictors of occupational attainment.

In Table 5 we then check these results for ethnic minorities using the larger EMBES dataset, which also enables us to make finer differentiations between the minority groups. As with the MCDS data, models 2 supports the hypothesis that minority embeddedness has negative implications for economic activity; in the EM$B E S$ data embeddedness also has negative effects on em- ployment and occupational chances, providing greater support for Hypothesis 3. However, area deprivation in model 4 proves to have large and significant negative effects, and substantially reduces the estimated effect of embeddedness for all three outcomes. Indeed embeddedness remains significant only for the chances of employment. The other interesting finding from EMBES is that co-ethnic friends tend to have a negative effect on economic outcomes whereas co-ethnic organizations tend to have either a positive or a non-significant effect.

The latter result is in line with the research of Lancee (2012). Thus, informal bonding with co-ethnics is associated with lower chance of getting the really good jobs, in contrast with bridging social capital which involves ties with members of the mainstream. Note that the survey was administered however at the end of the economic crisis in the UK when perhaps minority contacts were particularly weakened. In contrast, formal bonding with co-ethnics through organizational participation seems to have if anything a positive effect, perhaps reflecting the additional cognitive and practical skills which organizational membership is believed to foster.

Thus, on the whole, it is the deprivation of the area that appears to be associated with the undermining of the economic prospects of individuals rather than the mere presence of ethnic minorities, supporting Hypothesis 2 and Hypothesis 4 . Only in the models restricted to minority members (Tables 4 and 5 ) do we find that economic outcomes are negatively associated with minority embeddedness. However, these negative effects are attenuated once we take account of area deprivation. Moreover, we do not find that white British respondents living in more deprived areas suffer disproportionately from greater diversity-on the contrary, in such scenarios their occupational attainment prospects improve.

\section{Discussion}

This paper examines the predictors of economic integration-economic activity, being in employment, and occupational status. Our central focus is a comparison of the effects of ethnic diversity and area deprivation. Do we find that diversity hinders the prospects for both majority and minority groups alike, or is area deprivation the main factor leading to poor economic outcomes? And do these processes operate in the same way for the white British majority group and for ethnic minorities, or do we find that there is an asymmetry in the patterns?

While the results from the different datasets differ in detail, we also have some rather clear-cut conclusions. First, area deprivation is a major source of poor economic outcomes both for the white British and for ethnic minorities. Secondly, the presence of minorities does not appear to have any harmful effects for the White British-in none of the models in Table 3 were the effects negative. Thirdly, in the case of minorities, embeddedness did prove to have some negative effects although these were attenuated by controls for area deprivation. 
COGITATIO

Table 3. Labour market outcomes of white British respondents. Source: MCDS (2010)

\begin{tabular}{|c|c|c|c|c|c|c|c|c|c|c|c|c|}
\hline & \multicolumn{4}{|c|}{ Activity } & \multicolumn{4}{|c|}{ Employment } & \multicolumn{4}{|c|}{ Occupation } \\
\hline & $\begin{array}{l}\text { Model } 1 \\
\text { Coef/se }\end{array}$ & $\begin{array}{l}\text { Model } 2 \\
\text { Coef/se }\end{array}$ & $\begin{array}{l}\text { Model } 3 \\
\text { Coef/se }\end{array}$ & $\begin{array}{l}\text { Model } 4 \\
\text { Coef/se }\end{array}$ & $\begin{array}{l}\text { Model } 1 \\
\text { Coef/se }\end{array}$ & $\begin{array}{l}\text { Model } 2 \\
\text { Coef/se }\end{array}$ & $\begin{array}{l}\text { Model } 3 \\
\text { Coef/se }\end{array}$ & $\begin{array}{l}\text { Model } 4 \\
\text { Coef/se }\end{array}$ & $\begin{array}{l}\text { Model } 1 \\
\text { Coef/se }\end{array}$ & $\begin{array}{l}\text { Model } 2 \\
\text { Coef/se }\end{array}$ & $\begin{array}{l}\text { Model } 3 \\
\text { Coef/se }\end{array}$ & $\begin{array}{l}\text { Model } 4 \\
\text { Coef/se }\end{array}$ \\
\hline InAge & $\begin{array}{l}0.343^{* * *} \\
(0.056)\end{array}$ & $\begin{array}{l}0.340 * * * \\
(0.057)\end{array}$ & $\begin{array}{l}0.320 * * * \\
(0.058)\end{array}$ & $\begin{array}{l}0.317^{* * *} \\
(0.066)\end{array}$ & $\begin{array}{c}0.113^{* *} \\
(0.048)\end{array}$ & $\begin{array}{l}0.100 * * \\
(0.050)\end{array}$ & $\begin{array}{c}0.085^{*} \\
(0.047)\end{array}$ & $\begin{array}{c}0.086 * \\
(0.044)\end{array}$ & $\begin{array}{l}0.203^{* * *} \\
(0.041)\end{array}$ & $\begin{array}{l}0.194^{* * * *} \\
(0.040)\end{array}$ & $\begin{array}{l}0.171 * * * \\
(0.042)\end{array}$ & $\begin{array}{l}0.283^{* * *} \\
(0.049)\end{array}$ \\
\hline Gender & $\begin{array}{c}-0.072 * \\
(0.039)\end{array}$ & $\begin{array}{c}-0.077^{* *} \\
(0.039)\end{array}$ & $\begin{array}{c}-0.084^{* *} \\
(0.039)\end{array}$ & $\begin{array}{c}-0.083^{* *} \\
(0.041)\end{array}$ & $\begin{array}{l}0.078 * * \\
(0.032)\end{array}$ & $\begin{array}{c}0.074^{* *} \\
(0.030)\end{array}$ & $\begin{array}{l}0.068^{* *} \\
(0.029)\end{array}$ & $\begin{array}{l}0.068 * * \\
(0.027)\end{array}$ & $\begin{array}{c}-0.040 \\
(0.033)\end{array}$ & $\begin{array}{c}-0.055^{*} \\
(0.033)\end{array}$ & $\begin{array}{c}-0.058^{*} \\
(0.033)\end{array}$ & $\begin{array}{c}-0.033 \\
(0.034)\end{array}$ \\
\hline Marital status & $\begin{array}{l}0.116^{* *} \\
(0.040)\end{array}$ & $\begin{array}{l}0.110 * * \\
(0.039)\end{array}$ & $\begin{array}{l}0.110^{* *} \\
(0.039)\end{array}$ & $\begin{array}{l}0.115^{* *} \\
(0.039)\end{array}$ & $\begin{array}{l}0.070 * * \\
(0.032)\end{array}$ & $\begin{array}{l}0.061^{* *} \\
(0.031)\end{array}$ & $\begin{array}{c}0.058^{*} \\
(0.030)\end{array}$ & $\begin{array}{l}0.058^{* *} \\
(0.029)\end{array}$ & $\begin{array}{c}-0.042 \\
(0.027)\end{array}$ & $\begin{array}{c}-0.040 \\
(0.026)\end{array}$ & $\begin{array}{c}-0.034 \\
(0.027)\end{array}$ & $\begin{array}{c}-0.036 \\
(0.029)\end{array}$ \\
\hline \multicolumn{13}{|c|}{ Minority Embeddedness } \\
\hline $\begin{array}{l}\text { Percentage } \\
\text { non-white } \\
\text { British }\end{array}$ & $\begin{array}{c}0.022 \\
(0.104)\end{array}$ & $\begin{array}{c}0.064 \\
(0.108)\end{array}$ & $\begin{array}{c}0.121 \\
(0.106)\end{array}$ & $\begin{array}{c}-0.047 \\
(0.112)\end{array}$ & $\begin{array}{c}0.048 \\
(0.077)\end{array}$ & $\begin{array}{c}0.079 \\
(0.079)\end{array}$ & $\begin{array}{c}0.104 \\
(0.072)\end{array}$ & $\begin{array}{c}0.031 \\
(0.065)\end{array}$ & $\begin{array}{l}0.245^{* *} \\
(0.090)\end{array}$ & $\begin{array}{l}0.383^{* * *} \\
(0.092)\end{array}$ & $\begin{array}{l}0.448^{* * *} \\
(0.092)\end{array}$ & $\begin{array}{c}0.153^{*} \\
(0.091)\end{array}$ \\
\hline $\begin{array}{l}\text { Co-ethnic } \\
\text { Organization }\end{array}$ & & $\begin{array}{c}0.060 \\
(0.046)\end{array}$ & $\begin{array}{c}0.046 \\
(0.047)\end{array}$ & $\begin{array}{c}0.003 \\
(0.045) \\
\end{array}$ & & $\begin{array}{c}0.053 \\
(0.036)\end{array}$ & $\begin{array}{c}0.040 \\
(0.035)\end{array}$ & $\begin{array}{c}0.017 \\
(0.033)\end{array}$ & & $\begin{array}{l}0.172 * * * \\
(0.037)\end{array}$ & $\begin{array}{l}0.160 * * * \\
(0.036)\end{array}$ & $\begin{array}{l}0.095^{* *} \\
(0.036)\end{array}$ \\
\hline $\begin{array}{l}\text { Co-ethnic } \\
\text { Friends }\end{array}$ & & $\begin{array}{c}-0.052 \\
(0.097)\end{array}$ & $\begin{array}{c}-0.066 \\
(0.094)\end{array}$ & $\begin{array}{c}-0.010 \\
(0.087)\end{array}$ & & $\begin{array}{c}-0.055 \\
(0.073)\end{array}$ & $\begin{array}{c}-0.074 \\
(0.077)\end{array}$ & $\begin{array}{c}-0.045 \\
(0.067)\end{array}$ & & $\begin{array}{c}-0.135^{* *} \\
(0.051)\end{array}$ & $\begin{array}{c}-0.129 * * \\
(0.050)\end{array}$ & $\begin{array}{c}-0.064 \\
(0.067)\end{array}$ \\
\hline \multicolumn{13}{|l|}{ Deprivation } \\
\hline Inimd & & & $\begin{array}{c}-0.103^{* *} \\
(0.032)\end{array}$ & $\begin{array}{c}-0.071^{* *} \\
(0.032)\end{array}$ & & & $\begin{array}{c}-0.052^{* *} \\
(0.024)\end{array}$ & $\begin{array}{c}-0.038^{*} \\
(0.021)\end{array}$ & & & $\begin{array}{c}-0.105^{* * *} \\
(0.024)\end{array}$ & $\begin{array}{c}-0.042^{*} \\
(0.024)\end{array}$ \\
\hline $\begin{array}{l}\text { Secondary } \\
\text { (ref: Basic) }\end{array}$ & & & & $\begin{array}{l}0.244 * * * \\
(0.066)\end{array}$ & & & & $\begin{array}{l}0.132 * * * \\
(0.036)\end{array}$ & & & & $\begin{array}{l}0.246 * * * \\
(0.061)\end{array}$ \\
\hline Tertiary & & & & $\begin{array}{l}0.362^{* * *} \\
(0.058)\end{array}$ & & & & $\begin{array}{l}0.161^{* * *} \\
(0.042)\end{array}$ & & & & $\begin{array}{l}0.611^{* * * *} \\
(0.054)\end{array}$ \\
\hline $\begin{array}{l}\text { Residential } \\
\text { Stability }\end{array}$ & & & & $\begin{array}{c}-0.007 \\
(0.025) \\
\end{array}$ & & & & $\begin{array}{c}-0.009 \\
(0.017) \\
\end{array}$ & & & & $\begin{array}{c}-0.039 * * \\
(0.017)\end{array}$ \\
\hline $\mathrm{N}$ & 625 & 625 & 625 & 625 & 466 & 466 & 466 & 466 & 864 & 864 & 864 & 864 \\
\hline
\end{tabular}

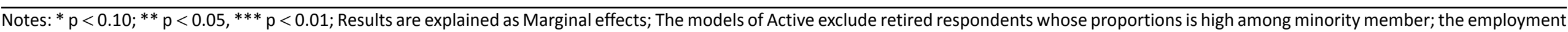
and occupational models focus only on the Active population. 
COGITATIO

Table 4. Labour market outcomes of minority respondents. Source: MCDS (2010).

\begin{tabular}{|c|c|c|c|c|c|c|c|c|c|c|c|c|}
\hline & \multicolumn{4}{|c|}{ Activity } & \multicolumn{4}{|c|}{ Employment } & \multicolumn{4}{|c|}{ Occupation } \\
\hline & $\begin{array}{l}\text { Model } 1 \\
\text { Coef/se }\end{array}$ & $\begin{array}{l}\text { Model } 2 \\
\text { Coef/se }\end{array}$ & $\begin{array}{l}\text { Model } 3 \\
\text { Coef/se }\end{array}$ & $\begin{array}{l}\text { Model } 4 \\
\text { Coef/se }\end{array}$ & $\begin{array}{l}\text { Model } 1 \\
\text { Coef/se }\end{array}$ & $\begin{array}{l}\text { Model } 2 \\
\text { Coef/se }\end{array}$ & $\begin{array}{l}\text { Model } 3 \\
\text { Coef/se }\end{array}$ & $\begin{array}{l}\text { Model } 4 \\
\text { Coef/se }\end{array}$ & $\begin{array}{l}\text { Model } 1 \\
\text { Coef/se }\end{array}$ & $\begin{array}{l}\text { Model } 2 \\
\text { Coef/se }\end{array}$ & $\begin{array}{l}\text { Model } 3 \\
\text { Coef/se }\end{array}$ & $\begin{array}{l}\text { Model } 4 \\
\text { Coef/se }\end{array}$ \\
\hline InAge & $\begin{array}{l}0.361^{* * *} \\
(0.068)\end{array}$ & $\begin{array}{l}0.361^{* * *} \\
(0.068)\end{array}$ & $\begin{array}{l}0.367^{* * *} \\
(0.068)\end{array}$ & $\begin{array}{l}0.368^{* * *} \\
(0.068)\end{array}$ & $\begin{array}{c}0.045 \\
(0.050)\end{array}$ & $\begin{array}{c}0.048 \\
(0.049)\end{array}$ & $\begin{array}{c}0.057 \\
(0.047)\end{array}$ & $\begin{array}{c}0.074 * \\
(0.043)\end{array}$ & $\begin{array}{l}0.163^{* * *} \\
(0.049)\end{array}$ & $\begin{array}{l}0.158^{* *} \\
(0.048)\end{array}$ & $\begin{array}{l}0.156^{* *} \\
(0.049)\end{array}$ & $\begin{array}{l}0.169 * * \\
(0.052)\end{array}$ \\
\hline Gender & $\begin{array}{l}-0.281^{* * *} \\
(0.036)\end{array}$ & $\begin{array}{l}-0.280 * * * \\
(0.036)\end{array}$ & $\begin{array}{l}-0.281 * * * \\
(0.037)\end{array}$ & $\begin{array}{l}-0.277^{* * *} \\
(0.038)\end{array}$ & $\begin{array}{c}-0.056 * * \\
(0.025)\end{array}$ & $\begin{array}{c}-0.055^{* *} \\
(0.025)\end{array}$ & $\begin{array}{c}-0.051 * * \\
(0.024)\end{array}$ & $\begin{array}{c}-0.046^{* *} \\
(0.023)\end{array}$ & $\begin{array}{c}-0.044 \\
(0.033)\end{array}$ & $\begin{array}{r}-0.048 \\
(0.033)\end{array}$ & $\begin{array}{c}-0.048 \\
(0.033)\end{array}$ & $\begin{array}{c}-0.022 \\
(0.030)\end{array}$ \\
\hline Marital status & $\begin{array}{c}0.077^{*} \\
(0.042)\end{array}$ & $\begin{array}{c}0.075^{*} \\
(0.042)\end{array}$ & $\begin{array}{c}0.074^{*} \\
(0.042)\end{array}$ & $\begin{array}{c}0.074^{*} \\
(0.043)\end{array}$ & $\begin{array}{c}0.051^{*} \\
(0.028)\end{array}$ & $\begin{array}{c}0.049 * \\
(0.028)\end{array}$ & $\begin{array}{c}0.044^{*} \\
(0.026)\end{array}$ & $\begin{array}{c}0.036 \\
(0.025)\end{array}$ & $\begin{array}{c}0.012 \\
(0.031)\end{array}$ & $\begin{array}{c}0.014 \\
(0.031)\end{array}$ & $\begin{array}{c}0.016 \\
(0.031)\end{array}$ & $\begin{array}{c}0.023 \\
(0.029)\end{array}$ \\
\hline \multicolumn{13}{|c|}{ Minority Embeddedness } \\
\hline $\begin{array}{l}\text { Percentage } \\
\text { non-white } \\
\text { British }\end{array}$ & $\begin{array}{c}-0.327^{* * *} \\
(0.096)\end{array}$ & $\begin{array}{c}-0.332 * * * \\
(0.098)\end{array}$ & $\begin{array}{c}-0.257^{* *} \\
(0.099)\end{array}$ & $\begin{array}{c}-0.243^{* *} \\
(0.100)\end{array}$ & $\begin{array}{c}-0.100 \\
(0.062)\end{array}$ & $\begin{array}{c}-0.107^{*} \\
(0.062)\end{array}$ & $\begin{array}{c}-0.051 \\
(0.059)\end{array}$ & $\begin{array}{c}-0.053 \\
(0.060)\end{array}$ & $\begin{array}{c}-0.125 \\
(0.080)\end{array}$ & $\begin{array}{c}-0.111 \\
(0.080)\end{array}$ & $\begin{array}{c}-0.059 \\
(0.092)\end{array}$ & $\begin{array}{c}-0.019 \\
(0.075)\end{array}$ \\
\hline $\begin{array}{l}\text { Co-ethnic } \\
\text { Organization }\end{array}$ & & $\begin{array}{c}0.044 \\
(0.060)\end{array}$ & $\begin{array}{c}0.040 \\
(0.061)\end{array}$ & $\begin{array}{c}0.046 \\
(0.059)\end{array}$ & & $\begin{array}{c}0.005 \\
(0.041)\end{array}$ & $\begin{array}{c}0.007 \\
(0.040)\end{array}$ & $\begin{array}{c}0.002 \\
(0.040)\end{array}$ & & $\begin{array}{c}-0.045 \\
(0.046)\end{array}$ & $\begin{array}{c}-0.045 \\
(0.047)\end{array}$ & $\begin{array}{c}-0.048 \\
(0.041)\end{array}$ \\
\hline $\begin{array}{l}\text { Co-ethnic } \\
\text { Friends }\end{array}$ & & $\begin{array}{c}-0.012 \\
(0.052)\end{array}$ & $\begin{array}{c}-0.010 \\
(0.051)\end{array}$ & $\begin{array}{c}-0.019 \\
(0.052)\end{array}$ & & $\begin{array}{c}-0.043 \\
(0.037)\end{array}$ & $\begin{array}{c}-0.046 \\
(0.036)\end{array}$ & $\begin{array}{c}-0.048 \\
(0.035)\end{array}$ & & $\begin{array}{r}0.105^{* *} \\
(0.040)\end{array}$ & $\begin{array}{r}0.106 * * \\
(0.040)\end{array}$ & $\begin{array}{r}0.098 * * \\
(0.038)\end{array}$ \\
\hline \multicolumn{13}{|l|}{ Deprivation } \\
\hline Inimd & & & $\begin{array}{c}-0.062^{*} \\
(0.036)\end{array}$ & $\begin{array}{c}-0.043 \\
(0.037)\end{array}$ & & & $\begin{array}{c}-0.051^{* *} \\
(0.025)\end{array}$ & $\begin{array}{c}-0.043^{*} \\
(0.026)\end{array}$ & & & $\begin{array}{c}-0.041 \\
(0.028)\end{array}$ & $\begin{array}{r}-0.010 \\
(0.023)\end{array}$ \\
\hline $\begin{array}{l}\text { Secondary } \\
\text { (ref: Basic) }\end{array}$ & & & & $\begin{array}{l}0.159 * * \\
(0.060)\end{array}$ & & & & $\begin{array}{c}0.046 \\
(0.031)\end{array}$ & & & & $\begin{array}{c}0.114 \\
(0.087)\end{array}$ \\
\hline Tertiary & & & & $\begin{array}{l}0.286^{* * *} \\
(0.061)\end{array}$ & & & & $\begin{array}{c}0.065^{*} \\
(0.036)\end{array}$ & & & & $\begin{array}{l}0.407^{* * *} \\
(0.064)\end{array}$ \\
\hline $\begin{array}{l}\text { Residential } \\
\text { Stability }\end{array}$ & & & & $\begin{array}{c}0.025 \\
(0.022)\end{array}$ & & & & $\begin{array}{c}-0.011 \\
(0.014)\end{array}$ & & & & $\begin{array}{c}-0.003 \\
(0.018)\end{array}$ \\
\hline $\mathrm{N}$ & 727 & 727 & 727 & 727 & 466 & 466 & 466 & 466 & 786 & 786 & 786 & 786 \\
\hline
\end{tabular}

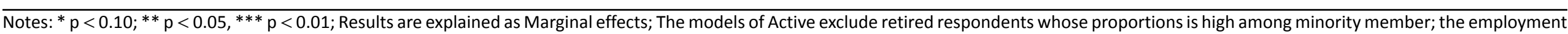
and occupational models focus only on the Active population, controls also for ethnic group and generation. 
COGITATIO

Table 5. Labour market outcomes of minority respondents. Source: EMBES (2010).

\begin{tabular}{|c|c|c|c|c|c|c|c|c|c|c|c|c|}
\hline & \multicolumn{4}{|c|}{ Activity } & \multicolumn{4}{|c|}{ Employment } & \multicolumn{4}{|c|}{ Occupation } \\
\hline & Model 1 & Model 2 & Model 3 & Model 4 & Model 1 & Model 2 & Model 3 & Model 4 & Model 1 & Model 2 & Model 3 & Model 4 \\
\hline LnAge & $\begin{array}{l}0.281 * * * \\
(0.039)\end{array}$ & $\begin{array}{l}0.285^{* * *} \\
(0.040)\end{array}$ & $\begin{array}{l}0.281^{* * *} \\
(0.040)\end{array}$ & $\begin{array}{l}0.289 * * * \\
(0.040)\end{array}$ & $\begin{array}{c}0.048 \\
(0.042)\end{array}$ & $\begin{array}{c}0.043 \\
(0.042)\end{array}$ & $\begin{array}{c}0.035 \\
(0.041)\end{array}$ & $\begin{array}{c}0.026 \\
(0.040)\end{array}$ & $\begin{array}{c}0.055 \\
(0.058)\end{array}$ & $\begin{array}{c}0.059 \\
(0.058)\end{array}$ & $\begin{array}{c}0.040 \\
(0.059)\end{array}$ & $\begin{array}{c}0.014 \\
(0.063)\end{array}$ \\
\hline Gender & $\begin{array}{l}-0.243^{* * * *} \\
(0.020)\end{array}$ & $\begin{array}{c}-0.241^{* * *} \\
(0.020)\end{array}$ & $\begin{array}{l}-0.240^{* * *} \\
(0.020)\end{array}$ & $\begin{array}{l}-0.231^{* * *} \\
(0.020)\end{array}$ & $\begin{array}{l}-0.049^{* *} \\
(0.020)\end{array}$ & $\begin{array}{l}-0.049^{* *} \\
(0.020)\end{array}$ & $\begin{array}{c}-0.048^{* *} \\
(0.020)\end{array}$ & $\begin{array}{l}-0.047^{* *} \\
(0.019)\end{array}$ & $\begin{array}{l}0.084^{* *} \\
(0.027)\end{array}$ & $\begin{array}{l}0.086^{* *} \\
(0.028)\end{array}$ & $\begin{array}{l}0.086^{* *} \\
(0.028)\end{array}$ & $\begin{array}{l}0.103^{* * *} \\
(0.030)\end{array}$ \\
\hline Marital status & $\begin{array}{c}0.038^{*} \\
(0.020)\end{array}$ & $\begin{array}{c}0.038^{*} \\
(0.020)\end{array}$ & $\begin{array}{c}0.038^{*} \\
(0.020)\end{array}$ & $\begin{array}{l}0.044^{* *} \\
(0.020)\end{array}$ & $\begin{array}{l}-0.008 \\
(0.019)\end{array}$ & $\begin{array}{l}-0.005 \\
(0.019)\end{array}$ & $\begin{array}{c}-0.007 \\
(0.018)\end{array}$ & $\begin{array}{c}0.001 \\
(0.018)\end{array}$ & $\begin{array}{c}0.026 \\
(0.026)\end{array}$ & $\begin{array}{c}0.025 \\
(0.026)\end{array}$ & $\begin{array}{c}0.024 \\
(0.026)\end{array}$ & $\begin{array}{c}0.044 \\
(0.027)\end{array}$ \\
\hline \multicolumn{13}{|l|}{ Generation } \\
\hline $\begin{array}{l}\text { 1st+ citizen } \\
\text { (ref:1st) }\end{array}$ & $\begin{array}{c}-0.014 \\
(0.030)\end{array}$ & $\begin{array}{c}-0.021 \\
(0.030)\end{array}$ & $\begin{array}{c}-0.019 \\
(0.030)\end{array}$ & $\begin{array}{c}0.004 \\
(0.030)\end{array}$ & $\begin{array}{c}0.010 \\
(0.031)\end{array}$ & $\begin{array}{c}0.009 \\
(0.031)\end{array}$ & $\begin{array}{c}0.010 \\
(0.030)\end{array}$ & $\begin{array}{c}0.024 \\
(0.029)\end{array}$ & $\begin{array}{l}-0.156^{* * *} \\
(0.037)\end{array}$ & $\begin{array}{l}-0.154^{* * *} \\
(0.037)\end{array}$ & $\begin{array}{l}-0.151^{* * *} \\
(0.038)\end{array}$ & $\begin{array}{c}-0.108^{* *} \\
(0.041)\end{array}$ \\
\hline 1.5 & $\begin{array}{c}-0.025 \\
(0.035)\end{array}$ & $\begin{array}{c}-0.033 \\
(0.035)\end{array}$ & $\begin{array}{c}-0.032 \\
(0.035)\end{array}$ & $\begin{array}{c}-0.019 \\
(0.035)\end{array}$ & $\begin{array}{c}0.032 \\
(0.034)\end{array}$ & $\begin{array}{c}0.030 \\
(0.034)\end{array}$ & $\begin{array}{c}0.027 \\
(0.034)\end{array}$ & $\begin{array}{c}0.040 \\
(0.032)\end{array}$ & $\begin{array}{c}-0.061 \\
(0.047)\end{array}$ & $\begin{array}{l}-0.061 \\
(0.047)\end{array}$ & $\begin{array}{l}-0.065 \\
(0.047)\end{array}$ & $\begin{array}{c}-0.001 \\
(0.053)\end{array}$ \\
\hline 2nd & $\begin{array}{l}0.094^{* * *} \\
(0.027)\end{array}$ & $\begin{array}{l}0.084^{* *} \\
(0.027)\end{array}$ & $\begin{array}{l}0.084^{* *} \\
(0.027)\end{array}$ & $\begin{array}{l}0.086^{* *} \\
(0.028)\end{array}$ & $\begin{array}{c}0.022 \\
(0.031)\end{array}$ & $\begin{array}{c}0.018 \\
(0.031)\end{array}$ & $\begin{array}{c}0.016 \\
(0.031)\end{array}$ & $\begin{array}{c}0.022 \\
(0.030)\end{array}$ & $\begin{array}{c}-0.006 \\
(0.042)\end{array}$ & $\begin{array}{l}-0.010 \\
(0.043)\end{array}$ & $\begin{array}{l}-0.014 \\
(0.043)\end{array}$ & $\begin{array}{c}0.020 \\
(0.046)\end{array}$ \\
\hline \multicolumn{13}{|c|}{ Minority Embeddedness } \\
\hline $\begin{array}{l}\text { Proportion } \\
\text { Non-white British }\end{array}$ & $\begin{array}{c}-0.082^{*} \\
(0.042)\end{array}$ & $\begin{array}{c}-0.066 \\
(0.042)\end{array}$ & $\begin{array}{c}-0.024 \\
(0.045)\end{array}$ & $\begin{array}{l}-0.007 \\
(0.046)\end{array}$ & $\begin{array}{l}-0.161^{* * *} \\
(0.043)\end{array}$ & $\begin{array}{l}-0.153^{* * *} \\
(0.042)\end{array}$ & $\begin{array}{c}-0.098^{* *} \\
(0.044)\end{array}$ & $\begin{array}{l}-0.086^{* *} \\
(0.043)\end{array}$ & $\begin{array}{l}-0.128^{* *} \\
(0.065)\end{array}$ & $\begin{array}{c}-0.114^{*} \\
(0.066)\end{array}$ & $\begin{array}{c}-0.034 \\
(0.070)\end{array}$ & $\begin{array}{c}0.029 \\
(0.076)\end{array}$ \\
\hline $\begin{array}{l}\text { Co-ethnic } \\
\text { Organization } \\
\end{array}$ & & $\begin{array}{c}0.047^{* *} \\
(0.020) \\
\end{array}$ & $\begin{array}{c}0.046^{* *} \\
(0.020) \\
\end{array}$ & $\begin{array}{c}0.042^{* *} \\
(0.021) \\
\end{array}$ & & $\begin{array}{c}0.015 \\
(0.022) \\
\end{array}$ & $\begin{array}{c}0.016 \\
(0.022) \\
\end{array}$ & $\begin{array}{c}0.007 \\
(0.022) \\
\end{array}$ & & $\begin{array}{l}-0.030 \\
(0.030) \\
\end{array}$ & $\begin{array}{c}-0.029 \\
(0.031) \\
\end{array}$ & $\begin{array}{c}-0.033 \\
(0.033) \\
\end{array}$ \\
\hline $\begin{array}{l}\text { Co-ethnic } \\
\text { Friends }\end{array}$ & & $\begin{array}{c}-0.035^{*} \\
(0.019) \\
\end{array}$ & $\begin{array}{c}-0.033^{*} \\
(0.019) \\
\end{array}$ & $\begin{array}{c}-0.025 \\
(0.019) \\
\end{array}$ & & $\begin{array}{c}-0.005 \\
(0.018) \\
\end{array}$ & $\begin{array}{c}-0.004 \\
(0.018) \\
\end{array}$ & $\begin{array}{c}-0.002 \\
(0.018) \\
\end{array}$ & & $\begin{array}{c}-0.075^{* *} \\
(0.026)\end{array}$ & $\begin{array}{c}-0.076^{* *} \\
(0.026)\end{array}$ & $\begin{array}{c}-0.070^{* *} \\
(0.028)\end{array}$ \\
\hline \multicolumn{13}{|l|}{ Deprivation } \\
\hline LnIMD & & & $\begin{array}{c}-0.058^{* *} \\
(0.023)\end{array}$ & $\begin{array}{c}-0.042^{*} \\
(0.023)\end{array}$ & & & $\begin{array}{c}-0.078^{* *} \\
(0.029)\end{array}$ & $\begin{array}{c}-0.056^{* *} \\
(0.028)\end{array}$ & & & $\begin{array}{c}-0.081^{* *} \\
(0.026)\end{array}$ & $\begin{array}{c}-0.047^{*} \\
(0.026)\end{array}$ \\
\hline $\begin{array}{l}\text { Secondary } \\
\text { (ref: Basic) }\end{array}$ & & & & $\begin{array}{l}0.158^{* * *} \\
(0.036)\end{array}$ & & & & $\begin{array}{l}0.071^{* *} \\
(0.036)\end{array}$ & & & & $\begin{array}{c}-0.171^{* *} \\
(0.069)\end{array}$ \\
\hline Tertiary & & & & $\begin{array}{l}0.249 * * * \\
(0.032)\end{array}$ & & & & $\begin{array}{l}0.197^{* * *} \\
(0.036)\end{array}$ & & & & $\begin{array}{l}0.284^{* * *} \\
(0.067)\end{array}$ \\
\hline $\mathrm{N}$ & 2485 & 2485 & 2485 & 2485 & 1707 & 1695 & 1695 & 1695 & 1344 & 1337 & 1337 & 1337 \\
\hline
\end{tabular}

Notes: ${ }^{*} p<0.10 ; * * p<0.05,{ }^{* * *} p<0.01$; Results are explained as Marginal effects; The models of Active exclude retired respondents whose proportions is high among minority member; the employment and occupational models focus only on the Active population: controls also for ethnic group and generation.

Social Inclusion, 2017, Volume 5, Issue 1, Pages 21-32 
Concerns about the effects of competition from minorities on the economic fortunes of the White British do not therefore receive any support from our data. In contrast concerns about ethnic embeddedness appear not to be wholly without foundation. This is in line with recent research by Zuccotti and Platt (2016) who, using linked census data, show that growing up in areas of high minority embeddedness leads to lower levels of economic activity subsequently. They interpret this as due to the preservation of traditional gender norms and roles in homogeneous minority communities. This argument has considerable plausibility, although we note that, in our data, area deprivation attenuates these negative effects of minority embeddedness. This suggests that it may be the lack of alternative opportunities that may provide the conditions for traditional norms to be perpetuated. We suggest that policy-makers should concentrate on providing greater opportunities for people, white British and minority alike, who live in deprived communities.

\section{Acknowledgments}

We want to thank the Leverhulme Trust for funding the ODP of which team the two authors are members, and the nationally representative survey, Managing Cultural Diversity Study, used in this article. The EMBES 2010 has been funded by the ESRC.This research was made possible thanks to funding from the European Commission: grant number H2020 649255.

\section{Conflict of Interests}

The authors declare no conflict of interests.

\section{References}

Abascal, M., \& Baldassarri, D. (2015). Love thy neighbor? Ethnoracial diversity and trust reexamined. American Journal of Sociology, 121(3), 722-782.

Alba, R., \& Nee, V. (1997). Rethinking assimilation theory for a new era of immigration. International Migration Review, 826-874.

Alesina, A., \& La Ferrara, E. (2002). Who trusts others? Journal of Public Economics, 85(2), 207-234.

Cameron, D. (2011, February 5). Speech at the Munich Security conference. Retrieved from www.num ber10.gov.uk/news/pms-speech-at-munich-securityconference

Cameron, D. (2013). Speech on immigration and welfare reform. Retrieved from https://www.gov.uk/govern ment/speeches/david-camerons-immigration-speech

Casey, L. (2016). The Casey Review: A review into opportunity and integration. London: Department for Communities and Local Government.

Cutler, D. M., Glaeser, E. L., \& Vigdor, J. L. (1997). The rise and decline of the American ghetto. Retrieved from http://www.nber.org/papers/w5881.pdf

Dawkins, C. J. (2008). Reflections on diversity and social capital: A critique of Robert D. Putnam's "E Pluyibus Unum: Diversity and Community in the Twenty-First Century. The 2006 Johan Skytte Prize Lecture". Housing Policy Debate, 19(1), 208-217.

Demireva, N., \& Heath, A. (2014). Diversity and the civic spirit in British neighbourhoods: An investigation with MCDS and EMBES 2010 Data. Sociology, 48(4), 643-663.

Dustmann, C., \& Frattini, T. (2014). The fiscal effects of immigration to the UK. The Economic Journal, 124(580), F593-F643. doi:10.1111/ecoj.12181

Dustmann, C., Frattini, T., \& Halls, C. (2010). Assessing the fiscal costs and benefits of $A 8$ migration to the UK. Fiscal Studies, 31(1), 1-41.

Dustmann, C., Frattini, T., \& Preston, I. P. (2013). The effect of immigration along the distribution of wages. The Review of Economic Studies, 80(1), 145-173.

Feng, X., Flowerdew, R., \& Feng, Z. (2015). Does neighbourhood influence ethnic inequalities in economic activity? Findings from the ONS Longitudinal Study. Journal of Economic Geography, 15(1), 169-194.

Fryer Jr, R. G., Pager, D., \& Spenkuch, J. L. (2011). Racial disparities in job finding and offered wages. Retrieved from http://www.nber.org/papers/w17462.pdf

Goodhart, D. (2013). The British dream: Successes and failures of post-war immigration. London: Atlantic.

Heath, A., \& Brinbaum, Y. (2007). Guest editorial: Explaining ethnic inequalities in educational attainment. London: Sage Publications.

Heath, A., \& Demireva, N. (2014). Has multiculturalism failed in Britain? Ethnic and Racial Studies, 37(1), 161-180.

Heath, A., \& Yu, S. (2005). Explaining ethnic minority disadvantage. In A. Heath, J. Ermisch, \& D. Gallie (Eds.), Understanding social change (pp. 187-224). Oxford: Oxford University Press.

Kahanec, M. (2013). Labor mobility in an enlarged European Union. International Handbook on the Economics of Migration, 137-152.

Koopmans, R. (2015). Does assimilation work? Sociocultural determinants of labour market participation of European Muslims. Journal of Ethnic and Migration Studies, 1-20.

Lancee, B. (2012). The economic returns of bonding and bridging social capital for immigrant men in Germany. Ethnic and Racial Studies, 35(4), 664-683.

Laurence, J. (2011). The effect of ethnic diversity and community disadvantage on social cohesion: A multilevel analysis of social capital and interethnic relations in UK communities. European Sociological Review, 27(1), 70-89. doi:10.1093/Esr/Jcp057

Laurence, J., \& Heath, A. (2008). Predictors of community cohesion: Multi-level modelling of the 2005 Citizneship survey. Retrieved from http://www.learn ingandwork.org.uk/lifelonglearninginquiry/docs/CIT 0001.pdf?redirectedfrom=niace

Lessard-Phillips, L. (2015). Exploring the dimensionality of ethnic minority adaptation in Britain: An analy- 
sis across ethnic and generational lines. Sociology. doi: $10.1177 / 0038038515609030$

Letki, N. (2008). Does diversity erode social cohesion? Social capital and race in British neighbourhoods. Political Studies, 56(1), 99-126.

Luthra, R. R., Platt, L., \& Salamońska, J. (2014). Migrant diversity, migration motivations and early integration: The case of Poles in Germany, the Netherlands, London and Dublin (LEQS Paper 74). London: London School of Economics and Political Science.

Manacorda, M., Manning, A., \& Wadsworth, J. (2012). The impact of immigration on the structure of wages: Theory and evidence from Britain. Journal of the European Economic Association, 10(1), 120-151.

May, T. (2012). Home Secretary speech on 'An immigration system that works in the national interest'. Retrieved from https://www.gov.uk/government/ speeches/home-secretary-speech-on-an-immigration -system-that-works-in-the-national-interest

Patacchini, E., \& Zenou, Y. (2012). Ethnic networks and employment outcomes. Regional Science and Urban Economics, 42(6), 938-949.

Phillips, T. (2005). After 7/7: Sleepwalking to segregation. Speech given at the Manchester Council for Community Relations.

Portes, A., \& Rumbaut, R. (2001). Legacies. Berkeley: University of California Press.

Portes, A., \& Zhou, M. (1993). The new 2nd-generation: Segmented assimilation and its variants. Annals of the American Academy of Political and Social Science, 530, 74-96.

\section{About the Authors}

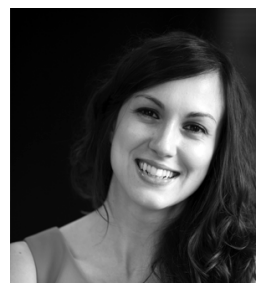

Neli Demireva (PhD) is a Senior Lecturer in Sociology at Essex University. Her research interests include migration, inter-ethnic ties, social cohesion, ethnic penalties and multiculturalism. She currently holds a BA grant on "Understanding the Ecology of Disadvantage: Betting Agents, Crime and the British Neighbourhood". From September 2015, she started working on the project: "GEMM: Growth, Equal Opportunities, Migration and Markets" (as part of the Horizon 2020 programme of the European Commission, "EURO-2-2014: The European growth agenda Research and Innovation action 4: Migration, prosperity and growth"). This project addresses the challenges and barriers that European countries face in managing the mobility of persons to realize competitiveness and growth.

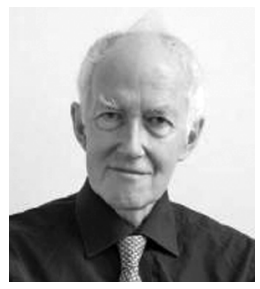

Anthony Heath (CBE, FBA) is currently Director of the Centre for Social Investigation, Nuffield College, Oxford and Professor of Sociology at CMIST, University of Manchester. His research interests cover social stratification, ethnic inequalities, national identity and social integration. His recent books include Unequal Attainments: Ethnic Educational Inequalities in Ten Western Countries (Proceedings of the British Academy), Migrants and Their Children: Generational Change in Patterns of Ethnic Minority Integration (Routledge), Hard Times: The Divisive Toll of the Economic Slump (Yale) and The Political Integration of Ethnic Minorities in Britain (OUP). He has carried out work for a range of public bodies including OECD, UNDP and a range of government departments in Britain. 